\title{
Kubbe-i Hadrâ'nın Karamanoğlu Döneminden Günümüze Değişen Çinileri
}

NACI BAKIRCI

Dr., Müze Müdürlüğü, Konya, Turkey, nacibakirci@hotmail.com

Geliş Tarihi / Received Date : 21.04.2020

Kabul Tarihi / Accepted Date : 23.06.2020

Yayın Tarihi / Published Date : 31.12.2020

\section{Atif/ Cite as}

Bakırcı, Naci. “Kubbe-i Hadrâ'nın Karamanoğlu Döneminden Günümüze Değişen Çinileri”. İstem, 18/36 (2020): 541-557. https://doi.org/10.31591/istem.833936

Öz

17 Aralık 1273 yılında vefat eden Mevlâna'nın mezarı üzerine Anadolu Selçuklu devlet adamlarından Muinüddin Pervane ile karısı Gürcü Hatun tarafından 1274 yılında Tebrizli Mimar Bedreddin'e türbe inşa ettirildiği bilinmektedir. Türbenin dış gövdesi ve külahı ilk kez Karamanoğlu Alâeddin Ali Bey zamanında dilimli olarak yaptıııımış ve çini ile kaplattırılmıştır. Osmanlılar zamanında depremler ve doğal afetler sonucu türbede meydana gelen çatlamalar neticesinde, çiniler yerlerinden dökülmüş bazen de çinilerin sırlarında bozulmalar meydana geldiği için dergâh şeyhlerinin talebi üzerine Osmanlı Sultanları tarafından türbe çinileri değiştirilmiștir. Yayınlanmış arşiv belgelerine göre Osmanlılar zamanında türbe çinileri beş defa Cumhuriyetin ilanından sonra da Eski Eserler ve Müzeler Genel Müdürlüğü tarafından 1949 ve 1964yılında Kütahya'da yaptırılan çinilerle iki defa yenilenmiştir. Türbenin 1964 yılında Kütahya'da yaptırılmış olan mevcut çinileri son yıllarda yerlerinden düşmeye başlamıştır. Çiniler üzerinde yapılan incelemelerde sırlarda bozulmalar olduğu da tespit edilmiştir. Türbenin çinilerinin tekrar değiştirilmesi için Kültür ve Turizm Bakanlığı tarafından, konunun uzmanlarından bir bilim kurulu oluşturulmuştur. Kurul üyelerinin yerinde yaptıkları toplantılardan sonra çinilerin değiştirilmesi kararlaştırılmıştır. Bunun üzerine Mimar Seyit Ahmet Biçer'e türbenin röleve, restorasyon ve restitüsyon çizimleri yaptırılmıştır.

Anahtar Kelimeler: Mevlâna, Mevlâna Türbesi, Karamanoğlu, Osmanlı, Çini.

\section{Abstract}

Tiles of the Kubbe-i Hadra Changing from Karamanoglu Period

It is known that a mausoleum was built in 1274 by Architect Bedreddin by the order of Muinuddin Pervane, a statesman of Anatolian Seljuk Sultanate, and his wife Gürcü Hatun on the tomb of Rumi, who passed away in 17th December 1273. Exterior body and the cone of the Mausoleum was built by Karamanid Alaeddin Bey in stripsand covered with tile for the first time.As a result of fractures on mausoleum caused by earthquakes and natural disasters during the time of Ottomans, tiles fell apart and ceramic glazes were damaged. On the demand of sheiks of dervish lodges, Ottoman Sultans or dered to replace the damaged ones. According to published archive documents, tiles of the mausoleum were replaced five times during Ottomans. After the foundation of the Republic of Turkey, tiles were replaced twice with tiles pro-

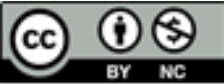


duced in Kütahya in 1949 and 1964 by the General Directorate of Ancient Arts and Museums. Presenttiles, produced in Kütahya in 1964, have been falling apart in recentyears. Deformation on the glazes of tiles has been detected during the examinations on the tiles. Ministry of Culture and Tourism has constituted a science committee of experts to renovate the tiles of The Mausoleum. After the meetings held in the area, science committee members decided to renovate the tiles. Inresponse, architect Seyit Ahmet Biçer completed the relievo, restoration, and restitution drawings.

Keywords: Mevlana, Mevlana Mausoleum, Karamanids, Ottomans, Tiles.

\section{Giriş}

Anadolu Selçuklulardan günümüze gelen mimari yapıların içerisinde Mevlâna Türbesi; Selçuklular, Karamanoğulları, Osmanlılar ile Cumhuriyet döneminde onarımlar görmüştür. Türbenin gövdesinde ve külahında bulunan çinileri deprem ve sırlarda bozulmalar ile yerlerinden dökülme gibi nedenlerle pek çok defa değiştirilmiştir. Bu onarımlarda değiştirilen çiniler mimarların, tarihçilerin, sanat tarihçilerin dikkatini çekmiştir. Oluş Arık bu durumu "depremler ve hatta saygı gibi nedenlerle türbenin devamlı restorasyon, ilave, değiştirme etkinlikleri olmuştur" diye ifade etmiştir. ${ }^{1}$

Mevlâna Türbesi'nin mimarisi ve tarihçesi hakkında pek çok yayın yapılmış olmakla birlikte onarımları ve değişen çinileri hakkında çok az yayın yapılmıştır. Bunun nedenleri olarak onarımlarda kullanılmış olan çini örneklerinin saklanamaması, onarımlara ait kitabenin çok az konulmuş olması ile tamirat defterlerinden yalnızca iki tanesinin yayınlanmış olmasına bağlayabiliriz.

1274 yııında yaptırıldığı kabul edilen türbenin üzerine ilk defa 1396 yılında Karaman oğlu Alâeddin Ali Bey tarafından 16 dilimli gövde ve külah yaptırılarak çinilerle kaplattırıldığını Şikari Karamanoğulları Tarihi kitabında belirtmiştir. Karamanoğulları döneminde yapılmış olan türbenin çinileri mevcut bilgilerimize göre Osmanlılar döneminde 1698, 1798, 1816, 1835, 1912 yılında beş defa değiştirilmiştir. Osmanlılar döneminde ilk defa 1698 yılında değiştirilmiş olan çinilerin daha erken bir tarihte değişip değiştirilmediği konusunda herhangi bir bilgiye sahip değiliz.

Karamanoğulları ve Osmanlılar dönemindeki yapılan onarımlardan çok az çini örneği günümüze gelmiştir. 1912 yılından yapılan onarımlarda sökülen çinilerin bir kısmının dergâhın Tarikatçı Bahçesine gömülmüş olduğunu, Mehmet Önder müze ziyaretlerinde Müze Müdürü Erdoğan Erol'a anlatmış, bunun üzerine söz konusu bahçede önce Yılmaz Önge daha sonra Müze Müdürlüğü tarafından yapılmış olan kazılarda muhtelif dönemlere ait çini parçaları bulunmuştur. Bulunan bu çini parçalarından başka Mevlâna Müzesinin Niyaz Penceresinde pencere tabanına döşenmiş türbenin yazı kuşağına ait çini örnekleri ile Konya Alâeddin Cami avlusunda bulunan Selçuklu Sultanlarının türbesindeki çinili sandukalarda, türbeye ait olduğu düşünülen birkaç çini parçası ikinci kullanım olarak değerlendirilmiştir. Bu örneklerden başka Karatay Müzesi ile Metropolitan Müzesi'nde türbeye ait çini örnekleri bulunmaktadır.

\footnotetext{
1 Oluş Arık, “Çinin Tarihçesine Kısa Bakış”, Anadolu Toprağının Hazinesi Çini Selçuklu ve Beylikler Çağı Çinileri, (İstanbul: Mass Yayınları, 2007), 164.
} 
1925 yılında dergâhların kapatılması üzerine müzeye dönüştürülen türbenin çinileri 1949 ve 1964 yılında iki defa Müzeler Genel Müdürlüğü tarafından değiştirilmiştir. 1964 yılında değiştirilmiş olan çiniler meydana gelen bozulmalardan dolayı Kültür ve Turizm Bakanlığı tarafından 2020 yılında hazırlanmış olan projeler doğrultusunda geleneksel tarzda imal ettirilecek çinilerle değiştirilecektir.

Makalemizde, müzelerde bulunan çini örnekleri birer birer ele alınmış, bu konuda yapılmış olan yayınlardan da yararlanılarak çinilerin imal dildiği şehirler ile dönemleri belirlenmeye çalışılmıştır.

\section{Onarımlar Hakkında Yapıımış Çalışmalar}

Türbenin çinileri hakkındaki Mevlâna Müzesinin Kurucu Müdürü Mehmet Yusuf, Konya Âsar-ı Atika Müzesi Muhtasar Rehberi isimli kitabında türbeyi anlatırken; “ Yeşil şöhretini veren, Anadolu'nun Konya ve havalisinin çiniciliğinin fevkalâde müterakki bulunduğu sıralarda Selçuk Veziri Emir Muinettin Pervane tarafından yaptırılıp sathına konulmuş olan yeşil Selçuklu kerpiçleridir." ifadesini kullanarak türbe çinilerinin Selçuklular tarafından yaptırılmış olduğunu belirtmiştir. ${ }^{2}$ Ancak hiçbir kaynakta türbenin Selçuklular döneminde çini ile kaplattırıldığı bilgisi bulunmamaktadır.

Mevlâna Türbesi'nin inşa edilmesini ve geçirdiği onarımları en kapsamlı şekilde Şahabettin Uzluk Mevlâna'nın Türbesi isimli kitabında geniş bir şekilde ele almıştır. ${ }^{3}$ Uzluk bu eserinde Ahmet Eflaki Dede'nin Menakubu-l Arifin (Ariflerin Menkıbeleri) isimli eserinde anlatılan menkıbelerden yola çıkarak türbenin günümüze kadar geçirdiği onarımları belgelere ve mimar kimliğine göre değerlendirmiştir.İbrahim Hakkı Konyalı Konya Tarihi isimli kitabında türbenin Gül Bahçesine yapılmasını, dergâhın vakıfları ile Huzur-ı PÎr'de bulunan mezar sandukalarının kitabelerini yayınlamıştır. ${ }^{4}$ ürbenin çinilerini anlatan ilk makale 1952 yılında Hakkı İzzet tarafından kaleme alınmıştır. ${ }^{5}$ Hakkı İzzet bu makalesinde 1949 yılında değiştirilen çinileri ele alarak Selçuklu dönemi çinilerinin malzeme ve hazırlanışı hakkında bilgiler vermiştir. İzzet; 1949 yılında değiştirilmiş olan çinilerin, yeşil ve düz sıralar halinde yerleştirilen Kütahya çinileri olduğunu, bu tamirden önceki çinilerin dik olarak döşendiğini, çinilerin gövdeye alt ve üstten çivilerle tutturulmuş olduğunu, yapılan son üç onarımda da külahın altında sır altı tekniğinde mavi zemin üzerine "Ayet-el Kürsî" yazısının bulunduğunu belirtmiştir. ${ }^{6}$

Yusuf Oğuzoğlu ile Selçuk Mülayim Mevlâna Türbesi hakkında 1109 /

\footnotetext{
2 Mehmet Yusuf, Konya Âsarı Atika Müzesi Muhtasar Rehberi (İstanbul: Alâeddin Yayınları, 1930), 12.

3 Şahabettin Uzluk, Mevlâna'nın Türbesi (Konya: Halkevi Yayınları, 1946), 73.

4 İbrahim Hakkı Konyalı, Abideleri ve Kitabeleri Ile Konya Tarihi (Konya: Yeni Kitap Basımevi Yayınları, 1964), 631.

5 Hakkı İzzet, "Mevlana Türbesinin Çini Kaplamaları ve Anadolu Selçuk Çiniciliğinin Sanat ve İşçilik Özellikleri”, Belleten XVI/64 (Ekim 1952), 577.

6 İzzet, Mevlana Türbesinin Çini Kaplamaları ve Anadolu Selçuk Çiniciliğinin Sanat ve İşçilik Özellikleri”, 578.
} 
1698 tarihli üç adet onarım belgesini 1984 yılında yayınlamışlardır. ${ }^{7}$ Belgeler türbenin değiştirilen çinilerinin İznik'te yaptırılmış olduğunu göstermesi bakımından önemlidir. Belgelerden bu onarımın Sultan II. Mustafa'nın saltanat yıllarında yaptırıldığını öğrenmekteyiz. Yayınlanmış olan 1no'lu belge de türbe çinilerinin İznik atölyelerinden tedarik olunması istenilmektedir. Ayrıca "nakş-ı kadim ve tarh-ı müstedimi" ifadesi ile yapılacak çinilerin aslına uygun olarak yapılması istenilmiştir. ${ }^{8}$ Yusuf Oğuzoğlu ile Selçuk Mülayim'in yayınlamış olduğu üç belge, Mevlâna'nın türbesinin Osmanlılar döneminde yapılan ilk çini değiştirilme işinin belgeleridir.

Mustafa Erdoğan 1816 tarihinde yapılmış olan tamirat ve çini değişiminin yazılı olduğu inşaat ve tamirat defterini yayınlayarak II. Mahmut döneminde Kütahya'da yaptırılmış olan çinileri tanıtmıştır. ${ }^{9}$ Erdoğan yayınlamış olduğu inşaat ve onarım defterinde Mevlâna Dergâhında 1816 yılında II. Mahmut tarafından yaptırılan onarımın büyüklüğünü ve Kütahya'da imal ettirilen çinilerin yapım teknikleri, ücreti ve nakliyesi hakkında bilgiler vermiştir.

1985 yılında Yılmaz Önge I. Milli Mevlâna Kongresinde sunmuş olduğu “Mevlâna Türbesinin Çini Tezyinatı” başlıklı bildirisinde; türbenin çinilerini Matrakçı Nasuh'un 1537 tarihli Beyan-ı Menazil-i Sefer-i Irakeyn-i Sultan Süleyman Han isimli eserinde yer alan Konya minyatüründe bulunan Mevlâna Türbesini plan ve çinileri bakımından değerlendirmiştir. Matrakçı Nasuh minyatüründe türbenin piramidal külahını, altıgen çinilerle kaplanmış şekilde resmetmiştir. Bu çizim türbenin günümüzdeki durumuna benzemez. Önge bu minyatürden başka Leon de Laborde'nin yapmış olduğu iki gravür ile Ressam Hüsnü Yusuf Bey'in Mevlâna Türbesi isimli resminde görülen çini süslemeleri, müzede bulunan çini örnekleri ile karşılaştırmıştır. ${ }^{10}$ Önge ayrıca Mevlâna Türbesi'nin 1274 yılında inşa edilmesinden sonra Karamanoğlu döneminde yaptırılmış olan gövde ve külah kısmına açıklık getirmiştir.

Hasan Özönder Mevlâna Türbesi'nin 1274 yılından 1982 yılına kadar geçirmiş olduğu onarım ve ilaveleri kronolojik olarak ele almış, 1698, 1798, 1816, 1866, 1912 ve 1965 yılında yapılmış olan tamiratlar hakkında geniş bilgiler vermiştir. ${ }^{11}$

Yusuf Küçükdağ Mevlâna Türbesi ve dergâh yapılarının 1251 H / 1835 M. tarihli tamir ve inşa defterini günümüz Türkçesine çevirerek Mustafa Erdoğan'dan sonra ikinci bir Tamirat Defterini yayınlamıştır. ${ }^{12}$ II. Mahmut dönemin-

7 Yusuf Oğuzoğlu - Selçuk Mülayim, “Konya Mevlâna Türbesi'nin Restorasyonu İle Alakalı H. 1109(1698) Tarihli Üç Belge", Arkeoloji Sanat Tarihi Dergisi 3 (1984), 115.

8 Oğuzoğlu - Mülayim, “Konya Mevlâna Türbesi'nin Restorasyonu Ille Alakalı H. 1109 (1698) Tarihli Üç Belge", 119.

9 Mustafa Erdoğan, “ikinci Mahmut Devrinde Mevlâna Türbesi”, (1-2-3-4-5), Yeni Konya Gazetesi, (12-13-14-15-16 Kasım 1951).

10 Yılmaz Önge, “Mevlâna Türbesi'nin Çini Tezyinatı”, I. Milli Mevlâna Kongresi (Aralık 1985): 400.

11 Hasan Özönder, "Mevlâna Türbe ve Külliyesinin Tamir ve İlaveler Kronolojisi”, Selçuk Dergisi 2 (Aralık 1989), 181.

12 Yusuf Küçükdağ, “1251H/1835M. Tarihli Mevlâna Türbesi ve Çelebi Efendi Konağı Tamir ve İnşası Defteri, Türkiyat Araştırmaları Dergisi 2 (Mayıs 1996), 181. 
de yapılmış olan tamirat çok geniş tutulmuştur. Tamir Defterinde İstanbul'dan ve Kayseri'den getirtilen ustaların isimleri, aldıkları yevmiyeler, Kütahya'da yaptırılmış olan çinilerin fiyatları ile kaç adet yaptırıldığı hakkında pek çok bilgi bulunmaktadır.

Mine Erdem 2017 yılında tamamladığı “Karamanoğlu Beyliği Mimarisinde Çini” konulu doktora çalışmasında türbenin eski resimleri ile mevcut çinilerini değerlendirmiş ve türbenin ölçekli çizimlerini yapmıştır. ${ }^{13}$

\section{Türbenin Çini Onarımları}

Mevlâna'nın 17 Aralık 1273 yılında vefatından sonra mezarı üzerine Alemeddin Kayser ve Muineddin Pervane ile karısı Gürcü Hatun'un Mevlâna'nın oğlu Sultan Veled'ten izin aldıktan sonra 1274 yılında Tebrizli Mimar Bedreddin'e türbe inşa ettirdiklerini Ahmet Eflaki'den öğreniyoruz. ${ }^{14}$ Fotoğrafta görülen dilimli gövdenin ve külahın iç kısmında yer alan küçük kubbeli örtünün Tebrizli Mimar tarafından yaptırılmış olduğu düşünülmektedir (Fot. 1). Türbenin kalem işi süslemeleri, güney duvarında yer alan kitabeye göre Osmanlılar döneminde II. Beyazıt'ın saltanat yıllarında (muhtemelen 1499 yılında) Halepli Nakkaş Abdurrahman'a yaptırımıştır. Mevlâna'nın mezar sandukasının batı ve doğusunda bulunan mezarlardan, Muzafferiddün Emir Alim Çelebi (ö.1277), Celâle Hatun (ö.1283), Melike Hatun (ö.1330), Vacit Çelebi (ö.1342), Şemseddin Âbid Çelebi (ö.1338) , Ulu Arif Çelebi (ö.1320) ile Zâhid Çelebi'nin (ö.1333) mezar sandukaları çiniden yapılmıştır. Celale Hatun ile Emir Alim Çelebi'nin sandukalarında mozaik ve kabartma çiniler, Vacit Çelebi'nin sandukasında da mozaik çini ile altıgen düz çiniler kullanılmıştır ( Fot. 2 - 3). Bu çinili sandukalardan hareketle Mevlâna Türbesi'nin hiç olmazsa güney duvarında çini kullanılmış olabileceği akla gelmektedir.

Yusuf Oğuzoğlu ile Selçuk Mülayim'in yayınlamış olduğu 1698 tarihli türbeye ait onarım belgesinde; "derûn-ı kubbenin kadimde müzeyyen divâr-ı nüzhetâsârı üzrinden nakş-ı kâşisinin mahallinden nümunesi getirtilüp...” ifadesi de türbenin güney duvarının çini ile kaplanmış olabileceğini göstermektedir. ${ }^{15}$ Ancak türbenin iç kısımlarından günümüze her hangi bir çini örneği gelmemiştir. 2019 yılında yapılan kalem işi restorasyonu çalışmalarında, türbenin tüm kalem işleri raspalanmış, güney duvarda bulunan çini desenli yağlıboyalı ahşap paravan sökülmüş, yapılan detaylı araştırmalarda paravanın arkasında kalan türbe duvarlarında hangi bir çini izine rastlanmıştır. ${ }^{16}$

Türbenin bilinen ilk büyük tamiratı Karamanoğlu Alâeddin Ali Bey (1357 -

\footnotetext{
13 Mine Erdem, Karamanoğlu Beyliği Mimarisinde Çini (Konya: Selçuk Üniversitesi, Sosyal Bilimler Enstitüsü, Doktora Tezi, 2017), 80.

14 Ahmet Eflaki, Ariflerin Menkıbeleri I (Istanbul: Hürriyet Yayınları, 1964), 376.

15 Oğuzoğlu-Mülayim, “Konya Mevlâna Türbesi'nin Restorasyonu Ile Alakalı H. 1109(1698) Tarihli Üç Belge", 121.

16 Ali Fuat Baysal, Kubbe-i Hadra Kalemişi Tezyinatı ve Yenilenmesi (Konya: Palet Yayınları, 2020), 95; Naci Bakırcı, "Mevlâna Müzesi Kubbe-i Hadrâ'nın Kalem i̇şi Süslemeleri ve Yapılan Restorasyon Çalışmaları", S.Ü. Sosyal Bilimler Enstitüsü Dergisi (Prof. Dr. Fuat Sezgin Özel Sayısı) (Aralık 2019), 3.
} 
1398) zamanındadır. Alâeddin Ali Bey'in Silifke seferi dönüşünde türbenin gövdesi ile külahı dilimli hale getirilmiş ve çini ile kaplattırılmıştır. ${ }^{17}$ Türbenin, Karamanoğulları dönemine ait çinileri hakkında son yıllara kadar bilgi sahibi değildik. Yılmaz Önge Mevlâna Türbesi'nin, Tarikatçı Bahçesi'nde çini yığınlarının içinde yaptığı araştırmalarda $28 \times 28 \mathrm{~cm}$ ebadında $4 \mathrm{~cm}$ kalınlığında çini parçaları bulmuş, bulduğu bu çini parçalarının Karamanoğulları döneminde yapılmış ilk çiniler olabileceğini belirtmiştir. ${ }^{18}$ Bu çiniler kavisli olup, türbenin 16 dilimli gövde yapısına uyum göstermektedir. Çini parçalarının hamurları, kirli sarı renkte, ince kumlu toprakla hazırlanmış, renkli sır tekniğinde yapılmış, hatayi üslupta, kıvrım dallar ve rumi motifleri ile geometrik şekilde bezenmiştir. Çinilerde az miktarda altın yaldız, beyaza yakın açık mavi, koyu mavi, lacivert, sarı ve siyah renkler kullanılmıştır.

Önge Tarikatçı Bahçesinde bulduğu çini parçalarından başka 1985 yılında semahane ve mescit kubbelerinin tamiri yapılırken çamur sıva arasında İznik işi çini örnekleri bulmuş, hatayi bezemeli, sülüs yazıları olan çini parçalarının Mevlâna Türbesi'nin gövde kısmında yer alan yazı kuşağına ait olabileceğini ifade etmiştir. ${ }^{19}$

Kubbe-i Hadra'nın 2020 yılında çinilerinin değiştirilmesi planlanırken, Karatay Müzesi'nde bulunan Mevlâna Türbesine ait çini parçalarının hepsi elden geçirilmiş ve bir tasnif çalışması yapılmıştır. Bu çalışmada; türbenin ilk çinileri olduğunu düşündüğümüz, birbirini tamamlayan iki çini parçası tespit edilmiştir. Karamanoğlu dönemi özellikleri gösteren bu çiniler Karatay Müzesi deposunda muhafaza edilmektedir (Fot. 4 - 5). Çini parçalarından birisi 33 x $28 \mathrm{~cm}$ diğeri $19 \times 25 \mathrm{~cm}$ ebatlarında, $4 \mathrm{~cm}$ kalınlığındadır. Çiniler kırmızıya yakın sarı hamurlu, renkli sır tekniğinde yapılmış, geometrik geçmeler ile hatayi ve kıvrım dallı rumi motifleriyle bezenmiştir. Rumi motifleri ile yapraklar açık ve koyu mavi, zemin çoğunlukla lacivert, çok azda siyah renklidir.

Müzede bulunan kavisli çini parçaları Önge'nin makalesinde belirttiği türbenin ilk çini örneklerine benzerlik göstermektedir. Bu çinilerin bir benzeri de Metropolitan Müzesi'nde bulunan, Mevlâna Türbesine ait XIV. yüzyıla tarihlendirilen çini parçasıdır (Fot. 6 - 7).

Karatay Müzesi'nde bulunan bu iki çini parçası, Karamanoğulları tarafından yaptırılmış olan Karaman İmaret Cami mihrabında yer alan renkli sır tekniğinde yapılmış çinilerle renk ve motif benzerliği göstermektedir (Fot. 8). Ayrıca Beylikler devri eseri olan Bursa Yeşil Cami çinilerinde görülen palmet ve rumi motifleriyle benzerlik göstermektedir (Fot.9). Çini parçalarının kalınlıkları, iç bükey kavisleri, Mevlâna Türbesi'nin dilimli gövdesi ile uyumlu olması, Metropolitan Müzesi'nde bulunan Mevlana Türbesi'ne ait çini ile aynı olmasından dolayı, türbenin ilk çini örnekleri olduğunu rahatça ifade edebiliriz.

\footnotetext{
17 Şikari, Karamanoğulları Tarihi, (Konya: Halkevi Yayınları, 1946), 107; Aynur Durukan, “Beylikler Dönemi Kültür Ortamından Bir Kesit”, Turkish Studies 9/10 Fall, 2014, 398.

18 Önge, "Mevlâna Türbesinin Çini Tezyinatı", 403.

19 Önge, “Mevlâna Türbesinin Çini Tezyinatı", 404.
} 
$\mathrm{Bu}$ ve diğer çini parçalarının malzeme ve sır analizleri, laboratuvarlarda yaptırılmış olup N.Erbakan Üniversitesi Dr. Öğr. Üyesi Çetin Öztürk tarafından ayrı bir makale olarak yayınlanacaktır.

XIV. Yüzyılda Karamanoğulları Dönemi'nde yapılmış olan türbe çinilerinin, Osmanlı Dönemi'nde ilk defa hangi tarihte değiştirilmiş olduğuna dair herhangi bir bilgiye sahip değiliz. Bilinen ilk büyük çini onarımı 1698 tarihinde yapılmıştır. Hasan Özönder; Sultan Mustafa'nın saltanat yıllarında 1698 tarihinde yapılmış olan onarım hakkında Sahip, Nesip Dede ile Nabi'nin manzumelerini ele alarak, deprem sonrası türbede meydana gelen çatlamaları ve yapılan tadilatları belirtmiştir. ${ }^{20} \mathrm{Bu}$ çalışmadan başka 1698 tarihinde gerçekleştirilmiş olan aynı onarım hakkında, Yusuf Oğuzoğlu - Selçuk Mülayim Başbakanlık Mühimme Defteri 110/228 numarada kayıtlı bulunan belgeleri yayınlamıştır. ${ }^{21}$ Yayınlanmış fermanda “...tarh-ı kadimine mutâbıknakş-ı mi'na-â-yı hoş nümalariyle bina olunmak üzre ve İznik karhânelerinden ol vec hüzre kâşisi tedarik olunması ..." yazılıdır. Bu bilgilerden türbe çinilerinin nakışı olarak İznik'te yaptırılmış olduğunu öğreniyoruz.

$\mathrm{Bu}$ onarıma ait olduğunu düşündüğümüz beş adet İznik işi çini parçası, Mevlâna Müzesi Gül Bahçesinde yapılan çalışmada bulunmuştur. 28 x 32.5, $23 \times 20 \mathrm{~cm}$ arasında değişen ebatlardaki çini parçaları $5 \mathrm{~cm}$ kalınlığındadır. Kavisli olan çini parçalarının türbenin gövdesinde bulunan yazı kuşağına aittir. Bu örnekler malzeme ve sırlarından dolayı İznik’te üretilmiş olan çini örnekleri ile benzerlik göstermektedir. Sarı renkli, ince gözenekli hamurdan yapılmış olan çini parçaları, lacivert zeminli olup, beyaz renkli yazı kuşağı, ince kıvrım dallı rumi motiflerle bezenmiştir. Çini parçalarının sülüs hatlı yazıları $3 \mathrm{~cm}$ kalem genişliğine sahiptir (Fot. 10 - 11).

1698 tarihli bu onarımdan yaklaşık yüz yıl sonra 1798 yılında kubbe ve gövdesinde oluşan çatlamalarda çinilerin zarar gördüğünü, Kütahya'da yaptırıIan çinilerle değiştirildiğini Sururi'nin tarih manzumesinden öğreniyoruz. ${ }^{22} \mathrm{Bu}$ onarım Mevlevi olduğu bilinen Sultan III. Selim'in saltanat yıllarında yapılmıştır. Onarıma ait arşiv belgesi veya tamirat defteri yayınlanmadığı için tamiratın detayları hakkında çok geniş bilgiye sahip değiliz. Ancak türbe çinilerinin tamamının değiştirilmiş olması muhtemeldir.

Osmanlı Dönemi'nde türbenin çinileri üçüncü defa II. Mahmut zamanında Halet Efendi'nin gayretiyle 1816 yılında yeniden değiştirilmiştir. Bu onarımda dergâh müştemilatı genişçe elden geçirilmiş bahçe duvarları ile döşeme taşları yenilenmiştir. Onarımda türbe tamir edilmiş, çinilerinin bir önceki çiniler gibi Kütahya'da imal ettirilen çinilerle değiştirilmiştir. Çinilerin kalaylı yassı çivilerle türbeye rapt olunduğunu, eski çinilerinde Tarikatçı Bahçesine gömüldüğünü Mustafa Erdoğan'ın 1951 yılında Yeni Konya gazetesinde beş gün arka arkaya

\footnotetext{
20 Özönder, “Mevlâna Türbe ve Külliyesinin Tamir ve İlaveler Kronolojisi”, 20.

21 Oğuzoğlu - Mülayim, “Konya Mevlâna Türbesi'nin Restorasyonu ile Alakalı H. 1109(1698) Tarihli Üç Belge", 116.

22 Özönder, “Mevlâna Türbe ve Külliyesinin Tamir ve İlaveler Kronolojisi”, 22.
} 
yayınladığı tamirat defteri ve belgelerden öğreniyoruz. ${ }^{23}$ Bu onarıma ait şair Pertev'in manzumesi levha olarak Mevlâna Müzesi'nde 272 envanter numarasında kayıtlıdır. Konyalı Aşık Şemi, türbeye rapt edilen çinilerin yeşil değil mavi renkte imal edildiğini, renk konusunda hayli sert münakaşalar yapııdığını ve imal edilen mavi renkli çinilerin türbede kullanıldığını belirtmiştir. ${ }^{24}$

Karatay Müzesi'nde bu onarıma ait mavi renkli sır altı tekniğinde üretilmiş, çivi delik yerleri olan Kütahya imalatı çini örnekleri bulunmaktadır (Fot. 12). Bu çinilerin türbenin gövdesine kalaylı çivilerle döşenmiştir.

1816 yılında değiştirilmiş olan türbenin çinileri, Osmanlı Dönemi'nde dördüncü defa II. Mahmut tarafından 1835 yılında tekrar değiştirilmiştir. Bu onarımda "Türbe üzerinde yer alan alemin onarılıp yaldızlandığını, Kubbe- Hadrâ üzerine ferş olunmak üzere 8000 adet çininin 25 paradan 5000 kuruşa Kütahya'da imal ettirildiğini, İmal edilen çinilerin Konya'ya nakli için katırcıya 30 yevmiye, 70 kuruştan 2100 kuruş, alemin tamiri için de kuyumcuya 1126 kuruş ödendiğini, türbede Mimar Es- Seyyid Mehmet Salih Usta ile Taşçı Hacı Mehmet Emin Usta' nın çalıştığını" Yusuf Küçükdağ'ın yayınlamış olduğu tamir ve inşa defterinden öğreniyoruz. ${ }^{25}$ Onarıma ait mermerden hazırlanmış olan tamir kitabesi Mevlâna Müzesi'nde 1250 envanter numarasında kayıtlıdır. Yusuf Küçükdağ tarafından okunan yuvarlak formlu kitabenin ortasında "Il. Mahmut'un tuğrası ile Adlî mahlası bulunmaktadır. Kitabenin kenarlarında Amele taşcı el-Hac Mehmet Emin efkaru'l-vera, ikinci satırda Ism-i Mimar Salih me'mur-ı bina-yı Kubbe-i Hadra" yazılıdır. Kütahya'da Hacı Mehmet Emin Usta tarafından imal edilmiş olan çiniler sıratlı tekniğinde koyu yeşil renklidir. $12 \mathrm{x}$ $23 \mathrm{~cm}$ ebatlarında, 1,5cm kalınlığındaki çiniler türbe gövdesine yatay vaziyette döşenmiştir. Bu onarıma ait çini örnekleri Karatay Müzesi'nde bulunmaktadır (Fot. 13).

Sultan Reşad döneminde 1912 yılında Türbe'nin çinileri Kütahya'da imal ettirilmiş çinilerle beşinci defa değiştirilmiştir. Şahabettin Uzluk, 1912 yılında gerçekleştirilen onarıma şahit olduğunu, çinilerin iyi fırınlanmamış oldukları için sırlarının kısa zamanda bozulduğunu belirtmiştir. ${ }^{26}$ Yılmaz Önge de; Veled Çelebi'nin düştüğü kayıtlara göre çinilerin altın yaldızıı yapıldığını ifade etmiştir. ${ }^{27}$ Karatay Müzesi'nde bu onarıma ait yeşil sırlı çinilerin üzerinde yer yer altın yaldız izleri görülmektedir (Fot. 14).

II. Mahmut ve Sultan Reşat döneminde kısa aralıklarla toplam üç kez değiştirildiği belirlenen Kütahya Çinileri'nin bu kadar sık aralıkla bozulmasının nedenleri araştırılmaya muhtaç bir konudur. Eldeki örneklerin malzeme ve sır analizleri yapıldıktan sonra bu konu tekrar değerlendirilebilecektir.

23 Erdoğan, “ikinci Mahmut Devrinde Mevlana Türbesi”, 2.

24 İbrahim Aczi Kendi, Konyalı Âşık Şem'i Konuşuyor (Konya: Yeni Kitap Basımevi, 1951), 37.

25 Küçükdağ, “1251H/1835M. Tarihli Mevlâna Türbesi ve Çelebi Efendi Konağı Tamir ve İş̧ası Defteri, 183.

26 Şahabeddin Uzluk, “istanbul'daki Eski Fatih Camii'nin Bir Benzeri Konya'da Selimiye Camii”, Vakıflar Dergisi IX (1971), 181.

27 Önge, Mevlâna Türbesinin Çini Tezyinatı", 405. 
1925 yılında tekke ve zaviyelerin kapatılmasından sonra Mevlâna Dergâhı müze olarak düzenlenmiştir. Bu tarihten sonra müzenin büyük onarımları müzelerin bağı bulunduğu Maarif Vekâleti ile Konya ve Mülhakatı Eski Eserleri Sevenler Derneği tarafından yapılmıştır. Türbenin 1912 yılında değiştirilmiş olan çinileri, fırınlanmadan kaynaklı sorunlar nedeniyle dökülmeye başlamış, 1949 yılında çiniler tekrar yenilenmiştir. Kütahya Metin Çini Fabrikasında mavi renkte sıratı tekniğinde imal ettirilmiş olan çiniler Eski Eserler ve Müzeler Genel Müdürlüğü Mimarlarından Ali Saim Ülgen'in nezaretinde türbeye dikine olarak döşettirilmiştir. Bu çiniler de kısa sürede sırlarında meydana gelen bozulmalardan dolayı dökülmeye başlamış, bunun üzerine külahtaki çiniler söktürülerek, külah kısmı ahşapla koruma altına alınmıştır.

Türbenin çinileri 1964 yılında Eski Eserler ve Müzeler Genel Müdürlüğü tarafından tekrar değiştirilmiştir. Kütahya Metin Çini Fabrikası'nda türbenin kasnağında kullanılmak üzere 850 adet düz, gövde ve külah kısmı için 5879 adet bombeli, yazı kuşağının alt ve üst kısmı için 374 adet, yazı kuşağı için 192 adet, külah ve yan kesme için 1080 adet olmak üzere toplam 8375 adet çini yaptırılmıştır.

Hazırlanan çiniler Yüksek Mimar Avni Kırkağaçlığlu, Arkeolog Mahmut Akok, Müze Müdür V. Necati Elgin, Edip Çinicioğlu'ndan (Metin Çini Adına) oluşan komisyon marifetiyle tek tek kontrolleri yapılarak 19.07.1964 tarihinde Müzeye teslim edilmiş, 18.09.1964 tarihinde de 78.733.92 lira keşif bedeli ile inalesi yapılarak Müteahhit Osman Korkmaz'a iş verilmiştir. Yapılan işlerin kesin kabulü 30.04.1966 yılında tamamlanmıştır. ${ }^{28}$

Çinilerin geçmişte kısa süre içinde dökülmüş olmasından dolayı bu onarımda türbenin dilimli gövdesi, 600 torba çimento kullanılarak $10 \mathrm{~cm}$ genişliğinde demirli beton kuşakla çevrilmiş bunun üzerine çiniler çimento harçla döşenmiştir. Bu onarımda çiniler beyaz hamurlu, yeşile yakın turkuaz renkli, 13,5 x 22 ebadında $2 \mathrm{~cm}$. kalınlığında ürettirilerek, türbe gövdesine boyuna olarak döşettirilmiştir. Onarıma ait fazla çiniler Konya Etnografya Müzesinde sandıklar içerisinde muhafaza edilmektedir (Fot. 15). Müze arşivinde türbe gövdesinin üst kısmında yer alan Ayetü-I Kürsi yazı kuşağının aydınger üzerine hazırlanmış yazı örneği de bulunmaktadır.

Günümüzde 1964 yılında yapıımış olan türbe çinilerinde nem ve yerinden düşmeler neticesinde bozulmalar olduğu gözlenmiştir. Çinilerin tekrar yenilenmesi için çalışmalar başlatılmıştır.

\section{Sonuç}

1274 yılında yaptırılmış olan Mevlâna Türbesi'nin dış gövde ile külah kısmı ilk defa Karamanoğlu Alâeddin Ali Bey (1357 - 1398) zamanında çini ile kaplattırımıştır. Osmanlı döneminde 1698 - 1912 yılları arasında İznik ve Kütahya'da imal ettirilen çinilerle beş, Cumhuriyet Dönemi'nde de 1949 ile 1964 yıIında iki defa değiştirilmiştir.

\footnotetext{
28 Konya Müze Müdürlüğünde Bulunan 1964 Tarihli Tamir Dosyası.
} 
Mevlâna Türbesi'nin günümüzdeki çinileri 1964 yılında Kütahya'da yaptırılmıştır. Geçen zaman içerisinde çinilerin sırlarında bozulmalar ve yerlerinden her gün birkaç parçanın düştüğü tespit edilmiştir. Türbenin iç kısmında yer alan kalem işlerini korumak ve türbenin bozulan çinilerinin değiştirilebilmesi için Kültür ve Turizm Bakanlığı tarafından, bir bilim kurulu oluşturulmuştur. Bilim kurulu üyeleri türbede yaptıkları çalışmalardan sonra çinilerin yeniden imal ettirilmesinin daha doğru olacağını belirtmiş ve bu yönde bir karar almıştır.

Yeni yaptırılacak çinilerin imalatına başlanmadan, Konya Müzelerinde buIunan Mevlâna Türbesine ait çini örneklerinin dönemleri ve imalat yerleri belirlenmeye çalışılmıştır. Müzelerimizde türbenin Karamanoğulları döneminde iki adet, Osmanlılar döneminde İznik'te yaptırılan olan çinilerinden beş adet, XIX yüzyılda Kütahya'da imal ettirilen çinilerinden daha çok çininin bulunduğu görülmüştür. Kütahya'da imal ettirilen çinilerin içerisinde turkuz rengin dışında bir adet yeşil renkli çini örneği bulunmuştur. Bu 1912 yılında türbe çinilerinin yeşil renkte yaptırılmış olduğunu göstermektedir. Diğer Kütahya çini örnekleri daha çok maviye yakın turkuaz renkte imal ettirilmiştir. 1965 yılında yapılmış olan çinilerin baskı tekniğinde, seramik hamurundan hazırlanmış ve kalaylı sır altı baskı tekniğinde imal edilmiş oldukları belirlenmiştir. Tespit edilen tüm çini örneklerinden malzeme ve renk analizleri yaptırımıştır. Bu sonuçlar Çetin Öztürk tarafından yayınlanacaktır.

Bilim kurulunda yeni yapılacak olan çinilerin, II. Mahmut döneminde yaptırılmış olan maviye yakın turkuaz renkte çinilere benzer şekilde, tap tap çini olarak imal ettirilmesine karar verilmiştir.

\section{Kaynaklar}

" Arık, Oluş. "Çininin Tarihçesine Kısa Bakış". Anadolu Toprağının Hazinesi Çini Selçuklu ve Beylikler Çağı Çinileri. İstanbul: Mass Yayınları, 2007.

" Bakırcı, Naci. “Mevlâna Müzesi Kubbe-i Hadrâ'nın Kalem İşi Süslemeleri ve Yapılan Restorasyon Çalışmaları". Selçuk Üniversitesi Sosyal Bilimler Enstitüsü Dergisi Prof. Dr. Fuat Sezgin Özel Sayısı (Aralık 2019), 322-338.

" Baysal, Ali Fuat. Kubbe-i Hadrâ Kalemişi Tezyinatı ve Yenilenmesi. Konya: Palet Yayınları, 2020.

" Durukan, Aynur. "Beylikler Dönemi Kültür Ortamından Bir Kesit”. Turkish Studies 9/10, 2014.

» Eflaki, Ahmet. Ariflerin Menkıbeleri. Ankara: Milli Eğitim Bakanlığı Yayınları, 1964.

" Erdem, Mine. Karamanoğlu Beyliği Mimarisinde Çini. Konya: Selçuk Üniversitesi, Sosyal Bilimler Enstitüsü, Doktora Tezi, 2017.

" Erdoğan, Mustafa. “ikinci Mahmut Devrinde Mevlana Türbesi1-2-3-4-5”. Yeni Konya Gazetesi 12-13-14-15-16 (Kasım 1951).

" İzzet, Hakkı. "Mevlâna Türbesinin Çini Kaplamaları ve Anadolu Selçuk Çiniciliğinin Sanat Ve İşcilik Özellikleri”. Belleten XVI/64, (1952), 577-583.

" Kendi, İbrahim Aczi. Konyalı Âşık Şem'i Konuşuyor. Konya: Yeni Kitap Basımevi Yayınları, 1951.

» Konyalı, Ibrahim Hakkı. Abideleri ve Kitabeleri Ile Konya Tarihi, Konya: Yeni Kitap Basımevi Yayınları, 1964.

» Küçükdağ, Yusuf. “1251 H/1835 M. Tarihli Mevlânâ Türbesi ve Çelebi Efendi Konağı Tamir ve Inşası Defteri”. Türkiyat Araştırmaları Dergisi 2 (Mayıs 1996), 181-206.

" Mehmet Yusuf. Konya Âsarı Atika Müzesi Muhtasar Rehberi. İstanbul: Alâeddin Yayınları, 1930.

» Müze Müdürlüğü. Tamir Dosyası. 1964.

» Oğuzoğlu, Yusuf - Mülayim, Selçuk. “Konya Mevlâna Türbesi'nin Restorasyonu Ille Alakalı 
H. 1109 (1698) Tarihli Üç Belge”. Arkeoloji Sanat Tarihi Dergisi 3, (1984),115-124.

» Önge, Yılmaz. "Mevlâna Türbesinin Çini Tezyinatı". I. Milli Mevlana Kongresi,(1985), 401408.

» Özönder, Hasan. “Mevlâna Türbe ve Külliyesinin Tamir ve İlaveler Kronolojisi”. Selçuk Dergisi 2, (1989), 181.

» Şikari, Karamanoğulları Tarihi. Konya: Halkevi Yayınları, 1946.

" Uzluk, Şahabettin. Mevlâna'nın Türbesi. Konya: Halkevi Yayınları, 1946.

» Uzluk, Şahabettin. “İstanbul'daki Eski Fatih Camii'nin Bir Benzeri Konya'da Selimiye Camii”. Vakıflar Dergisi IX. (1971),73-183.

\section{Fotoğraflar}

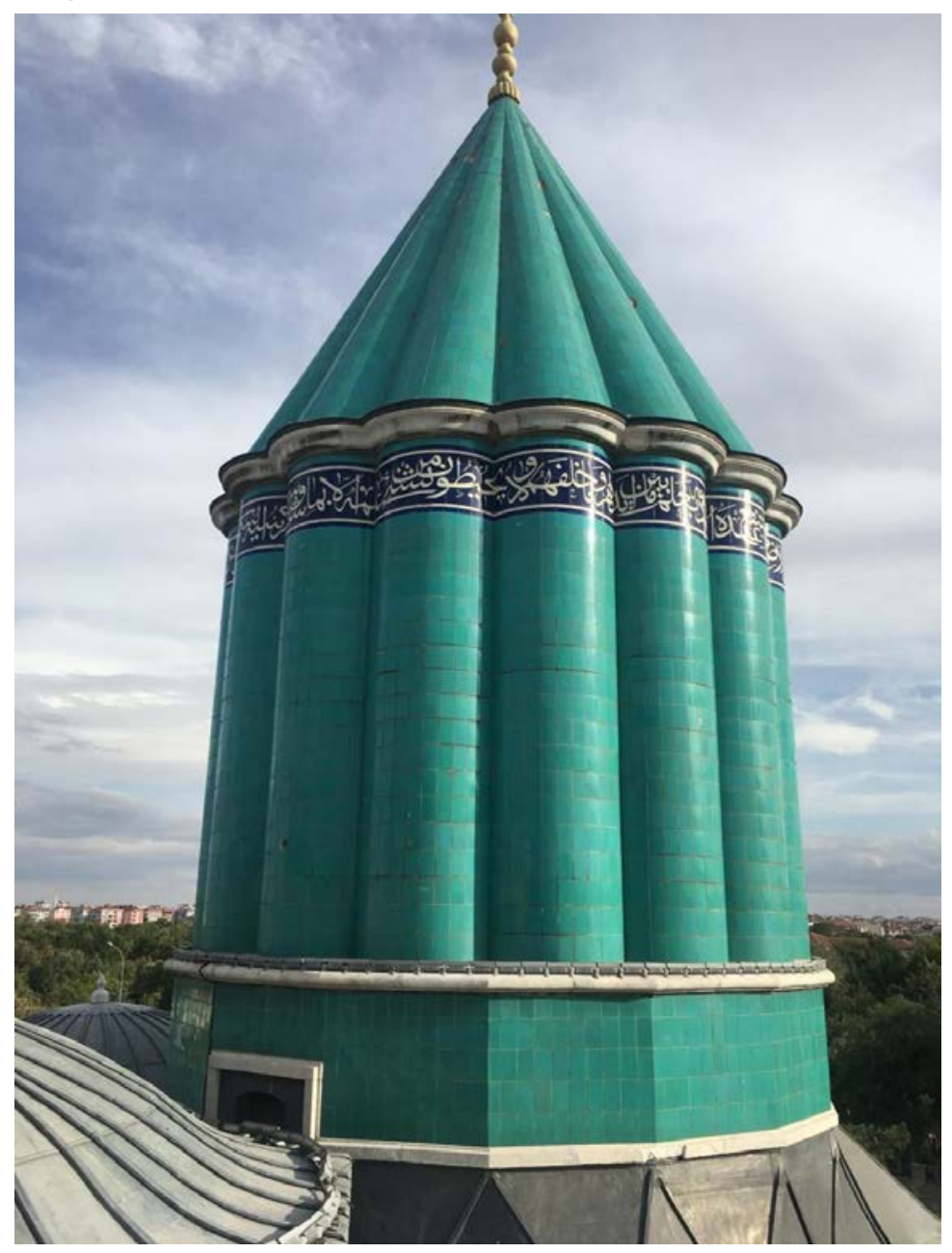

Fotoğraf 1: Mevlâna'nın Türbesi (Karamanoğlu döneminde yaptırılmış olan dilimli gövde ve külahın 1964 yılında değiştirilmiş olan günümüzdeki çinileri) 


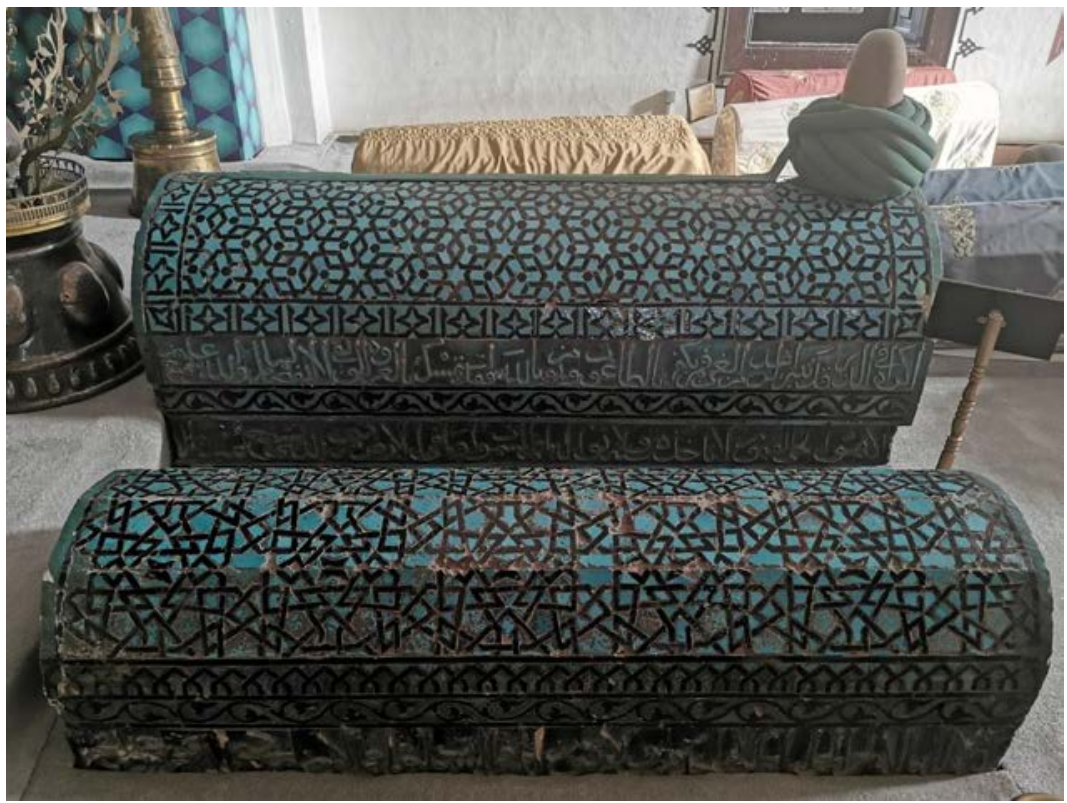

Fotoğraf 2: Mevlâna'nın mezarının batı yönünde yer alan Muzafferiddün Emir Alim Çelebi'nin 1277 tarihli çinili mezar sandukası ile 1283 tarihli Celale Hatun'un çiniden yapılmış mezar sandukası.

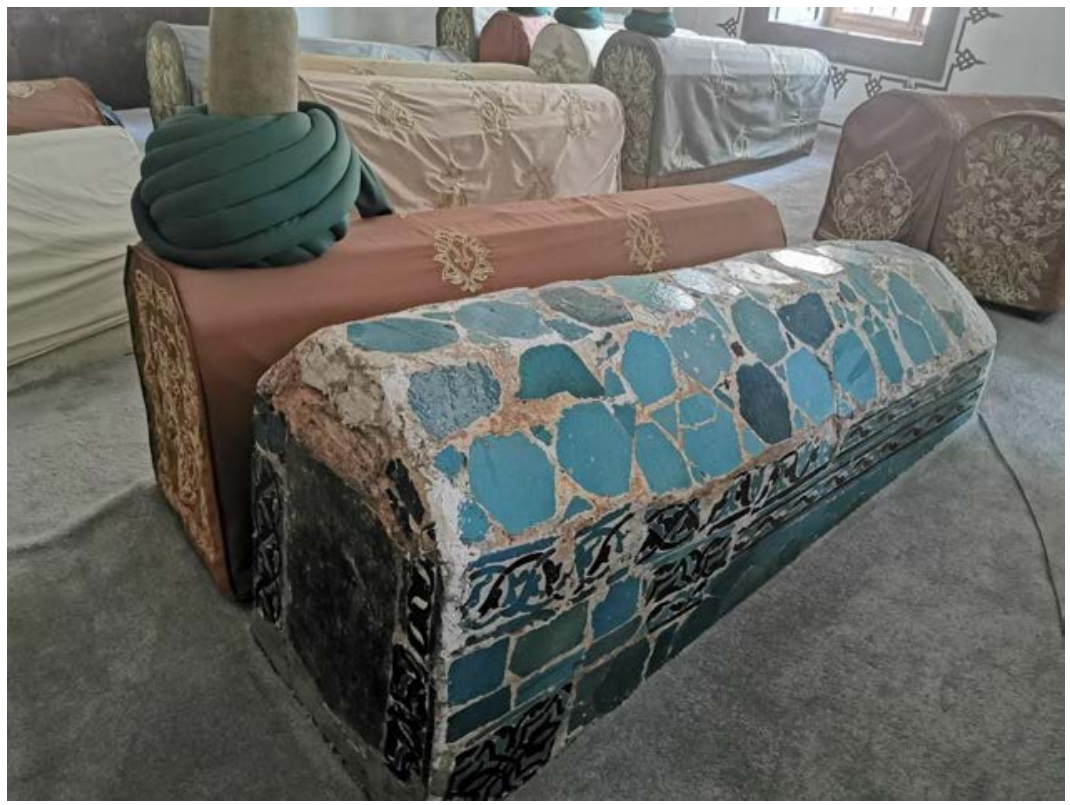

Fotoğraf 3: Mevlâna'nın mezarının doğu yönünde yer alan Sultan Veled'in oğlu Vacid Çelebi'nin 1342 tarihli mezar sandukası. 


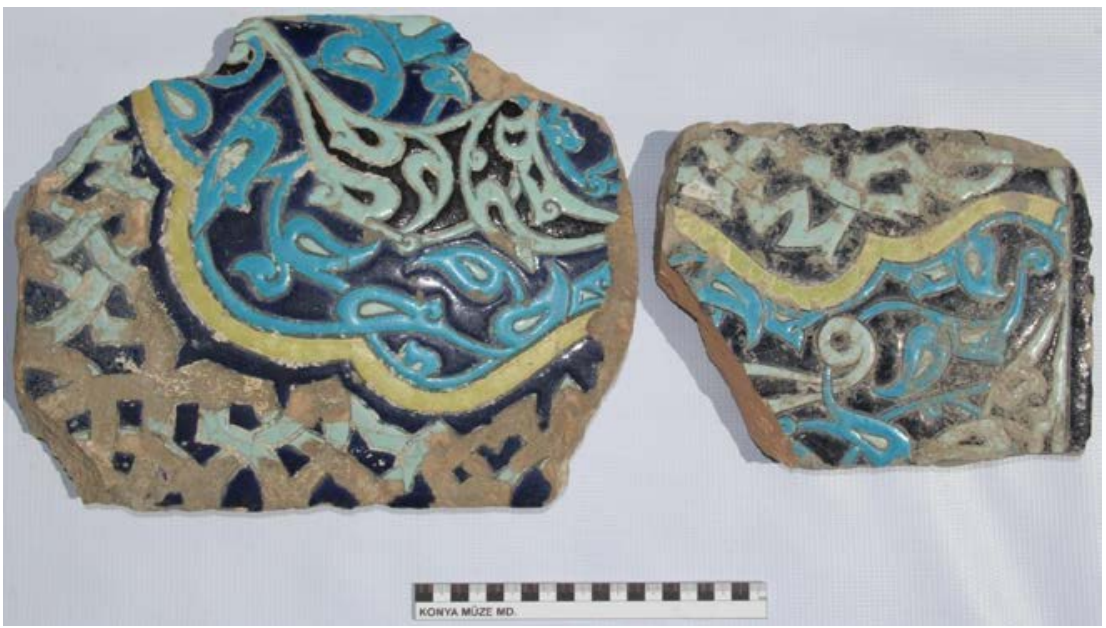

Fotoğraf 4: Kubbe-i Hadra'nın Mevlâna Müzesi Tarikatçı Bahçesi'nde bulunmuş olan Karamanoğlu Dönemi'nde yaptırımış olan ilk çini örnekleri.

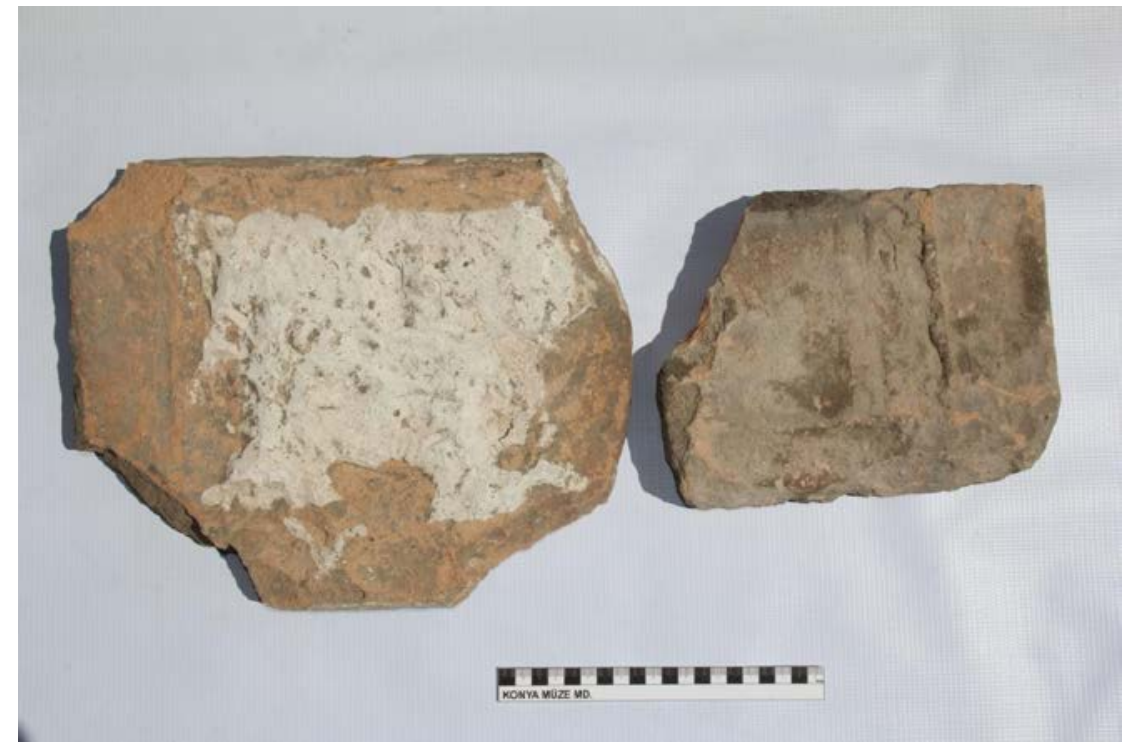

Fotoğraf 5: Kubbe-i Hadra'nın Mevlâna Müzesi Tarikatçı Bahçesi'nde bulunmuş olan Karamanoğlu Dönemi'nde yaptırılmış olan ilk çini örneklerinin sırt kısmından görünen hamuru ile harç kalıntılarından görünüm. 


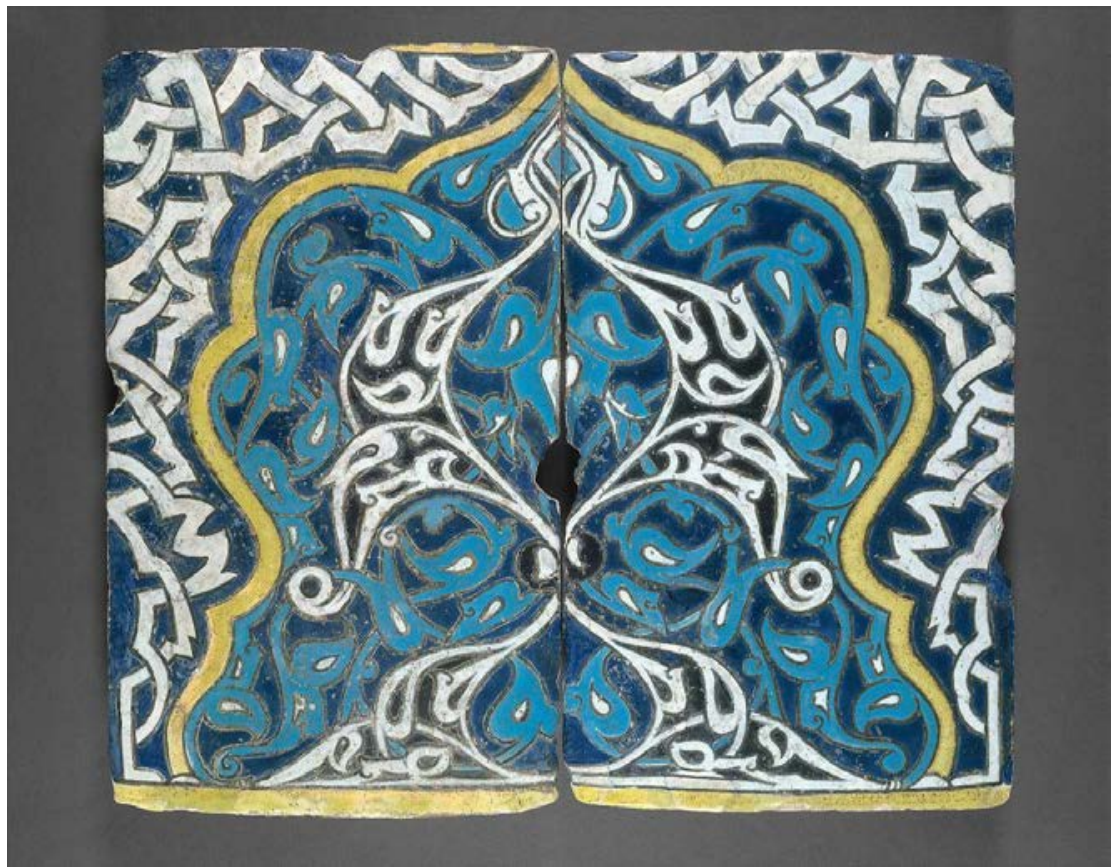

Fotoğraf 6: Kubbe-i Hadra'nın Metropolitan Müzesi'nde bulunan XIV. yy. Karamanoğlu Dönemi'nde yaptırılmış olan ilk çini örneği.

$\mathbf{i}$
$\mathbf{S}$
$\mathbf{T}$
$\mathbf{E}$
$\mathbf{M}$
$\mathbf{3} / 2020$

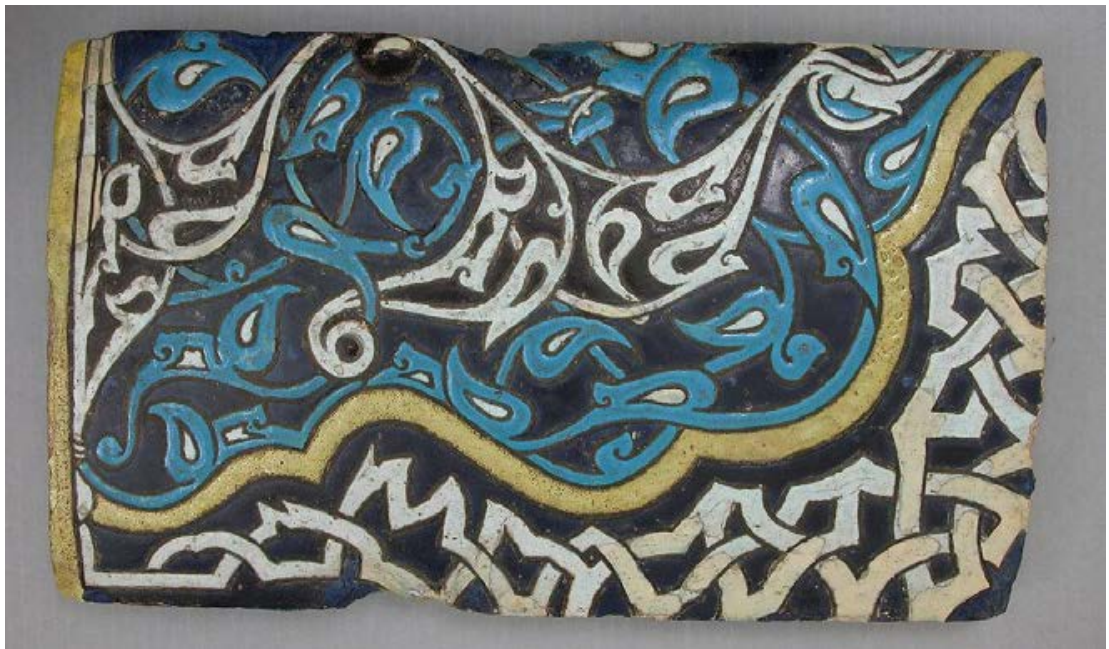

Fotoğraf 7: Kubbe-i Hadra'nın Metropolitan Müzesi'nde bulunan XIV. yy. Karamanoğlu Dönemi'nde yaptırılmış olan ilk çini örneği. 


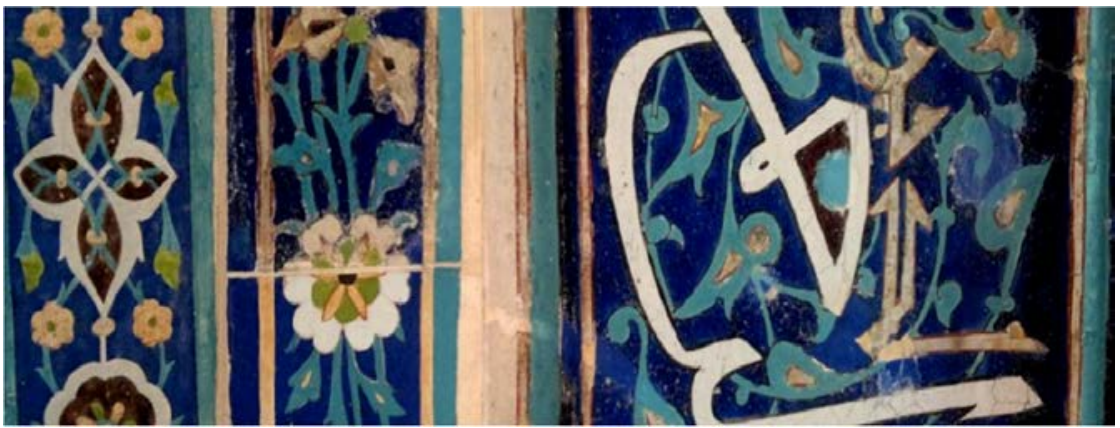

Fotoğraf 8: Karaman İbrahim Bey İmaret mihrabı, renkli sır teknikli çini örneği (Mine Erdem)

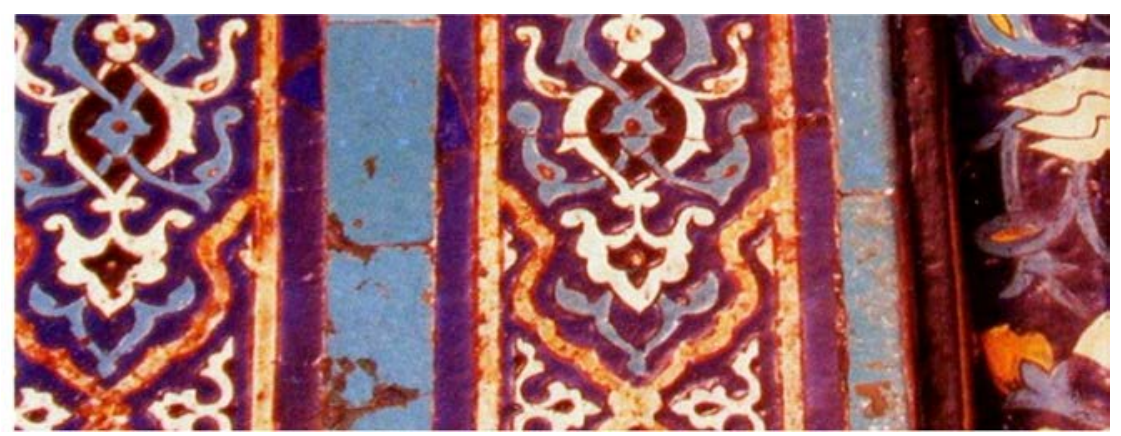

Fotoğraf 9: Bursa Yeşil Cami, renkli sır teknikli çini örneği (Mine Erdem'den
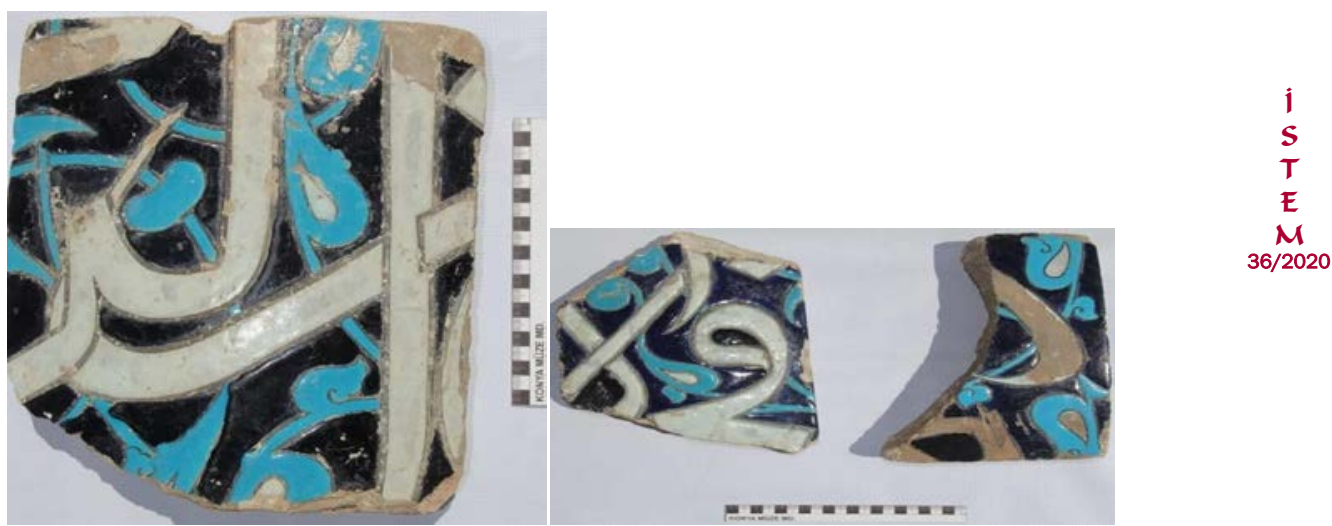

Fotoğraf 10-11: Karatay Müzesi'nde bulunan Kubbe-i Hadra'nın İznik'te yaptırılmış olan türbe çinileri. 


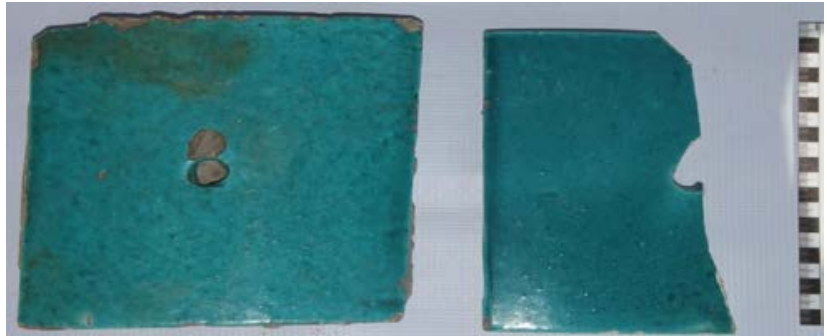

Fotoğraf 12: Tarikatçı Bahçesi'nde bulunmuş olan Kubbe-i Hadra'nın XIX. yy. da Kütahya'da yaptırılmış olan ortası çivi delikli çini örnekleri.

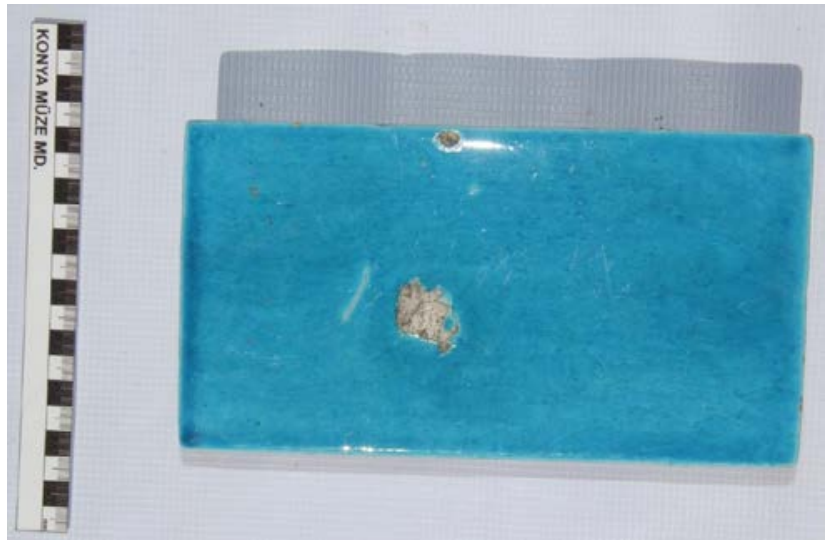

Fotoğraf 13: Tarikatçı Bahçesinde bulunmuş olan Kubbe-i Hadra'nın XIX. yy. da Kütahya'da yaptırımış olan mavi renkli çini örneği.

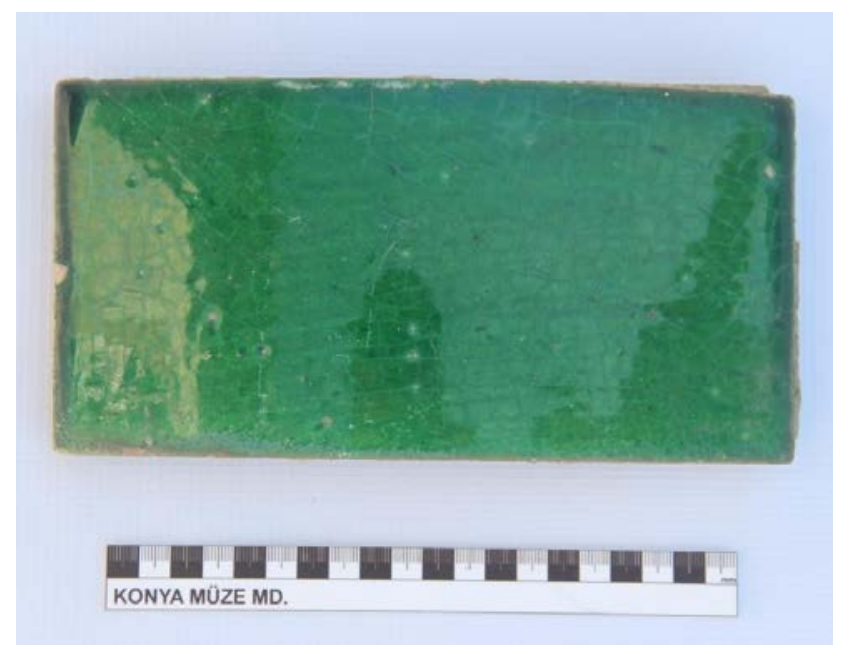

Fotoğraf 14: 1912 yılında Sultan Reşad tarafından Kütahya'da yaptıılan çini. 


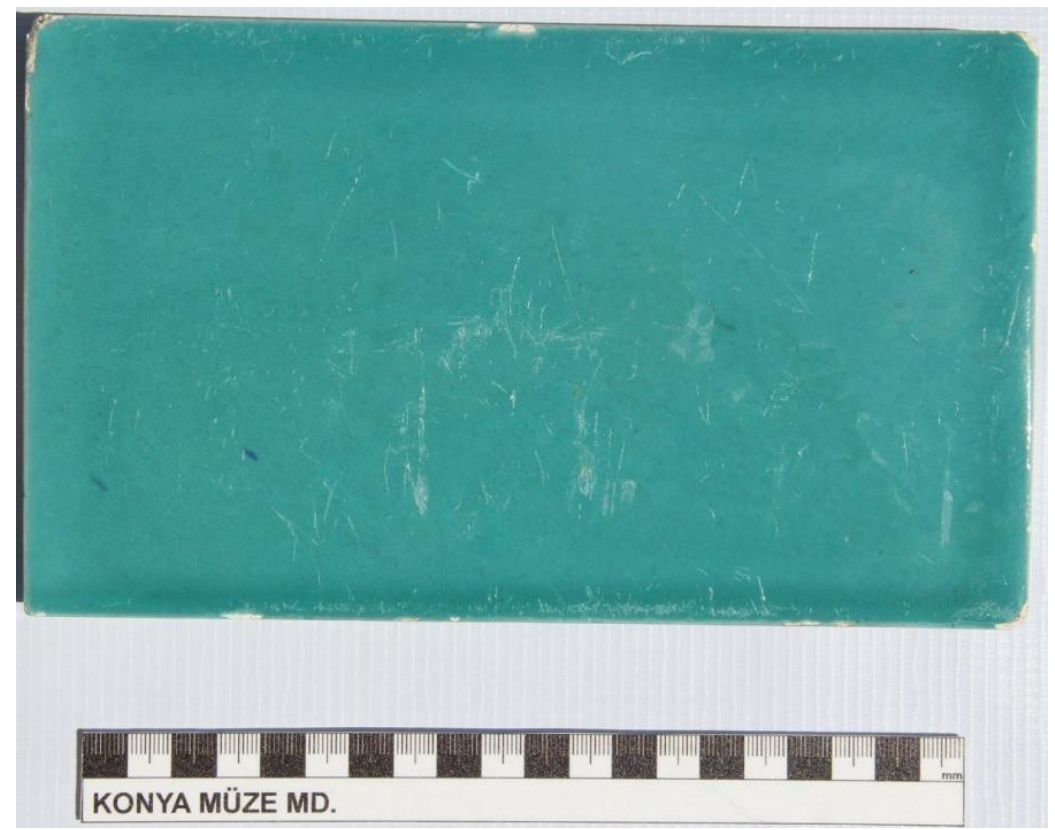

Fotoğraf 15: Türbenin 1964 yılında Kütahya'da yaptırılmış çini örneği. 